\title{
CHINESE INVESTMENT AND TRADE - STRENGTHENING TIES WITH CENTRAL AND EASTERN EUROPE
}

\author{
ANDREA ÉLTETŐ, ÁGNES SZUNOMÁR
}

\begin{abstract}
:
The economic expansion of China is one of the most spectacular cases of today's global economy, where this East Asian country is increasingly integrated through foreign direct investments (FDI) and rising trade flows. Chinese firms has been building strong economic ties with Asia, Latin America and Africa where they search for markets and natural resources. Developed economies of Europe and the United States also became their important targets recently, offering markets for Chinese products and assets Chinese firms lack. We can observe rising Chinese economic presence in Central and Eastern Europe (CEE) too. Investment inflows are currently expected to increase further due to recent political developments, while the intensity of trade has been growing too, especially with certain countries.
\end{abstract}

The aim of the paper is to analyse the characteristics of Chinese economic presence in CEE countries focusing on investment and trade flows. After the introductory section and the discussion of theory and literature, the paper presents the changing patterns and motivations of Chinese foreign economic relations. The main part of the paper describes the China-CEE economic relations highlighting the similarities and differences of Chinese practices in CEE and other developed economies. According to our first hypothesis, Chinese motivations and practices in the CEE region differ somewhat (a) from the developed countries' presence in the CEE region as well as (b) from the motivations and practices of Chinese companies in developing countries. As a second hypothesis we set that the crisis accelerated the Chinese companies' interest toward this region due to new opportunities for Chinese companies and increasing receptiveness from CEE side.

The first part of this paper examines Chinese investment in the six main CEE destination countries (Bulgaria, Czech Republic, Hungary, Poland, Romania, Slovakia), analyzing the most important sectors, motivations, trends and differences of FDI inflow. We apply the eclectic paradigm of Dunning for explaining Chinese investments, analyzing to what extent they are valid. The second part describes trade flows between China and the main CEE partners. We find that the bulk of foreign trade between CEE countries and China can be bound to certain products and certain multinational companies. Mutual trade flows thus are largely dependent on the activities of global value chains. Finally we draw some policy implications concerning mutual economic relationship.

\section{Keywords:}

China, Central and Eastern Europe, FDI, Global value chains, foreign trade

JEL Classification: F23, F10

\section{Authors:}

ANDREA ÉLTETŐ, Institute of World Economics, Centre for Economic and Regional Studies, Hungarian 
Academy of Sciences, Hungary, Email: elteto.andrea@krtk.mta.hu

ÁGNES SZUNOMÁR, Institute of World Economics, Centre for Economic and Regional Studies, Hungarian Academy of Sciences, Hungary, Email: szunomar.agnes@krtk.mta.hu

\section{Citation:}

ANDREA ÉLTETŐ, ÁGNES SZUNOMÁR (2016). Chinese investment and trade - strengthening ties with Central and Eastern Europe. International Journal of Business and Management, Vol. IV(1), pp. 24-48., 10.20472/BM.2016.4.1.002 


\section{Introduction ${ }^{1}$}

The economic expansion of China is one of the most spectacular cases of today's global economy, where this East Asian country is increasingly integrated through foreign direct investments (FDI) and rising trade flows. Chinese firms have been building strong economic ties with Asia, Latin America and Africa where they search for markets and natural resources. Developed economies of Europe and the United States also became their important targets recently, offering markets for Chinese products and assets Chinese firms lack. We can observe rising Chinese economic presence in Central and Eastern Europe (CEE) too. Investment inflows are currently expected to increase further due to recent political developments, while the intensity of trade has been growing too, especially with certain countries.

The aim of the paper is to analyse the characteristics of Chinese economic presence in CEE countries focusing on investment and trade flows. After the introductory section and the discussion of theory and literature, the paper presents the changing patterns and motivations of Chinese foreign economic relations. The main part of the paper describes the China-CEE economic relations highlighting the similarities and differences of Chinese practices in CEE and other developed economies. According to our first hypothesis, Chinese companies used to treat the region as a back door to European markets but recently their motivations have slightly expanded towards efficiency- and strategic asset seeking motives. As a second hypothesis we set that the crisis accelerated the Chinese companies' interest toward this region due to new opportunities for Chinese companies and increasing receptiveness from CEE side.

The first part of this paper examines Chinese investment in the six main CEE destination countries (Bulgaria, Czech Republic, Hungary, Poland, Romania, Slovakia), analyzing the most important sectors, motivations, trends and differences of FDI inflow. We apply the eclectic paradigm of Dunning for explaining Chinese investments, analyzing to what extent they are valid. The second part describes trade flows between China and the main CEE partners. We find that the bulk of foreign trade between CEE countries and China can be bound to certain products and certain multinational companies. Mutual trade flows thus are largely dependent on the activities of global value chains. Finally we draw some policy implications concerning mutual economic relationship.

\section{Theoretical framework and relevant literature on China-CEE relations}

Majority of research on motivations for FDI apply the eclectic or OLI paradigm by Dunning $(1992,1998)$ that states that firms will venture abroad when they possess firm-specific advantages, i.e. ownership (O) and internalization (I) advantages, and when they can utilize location $(L)$ advantages to benefit from the attractions these

This paper was supported by the 2015 scholarship of the Sasakawa Young Leaders Fellowship Fund and by the OTKA Fund project no. K115578 titled "Factors influencing export performance - a comparison of three European regions". 
locations are embedded with. Different types of investment incentives attract different types of FDI which Dunning (1992) divided into four categories: market-seeking, resource-seeking, efficiency-seeking and asset-seeking. Location advantages "comprise geographical and climate conditions, resource endowments, factor prices, transportation costs, as well as the degree of openness of a country and the presence of a business environment appropriate to ensure to a foreign firm a profitable activity" (Resmini, 2005, p 3). Much of the extant research and theoretical discussion is based on FDI outflows from developed countries for which market-seeking and efficiencyseeking FDI is most prominent (Buckley et al. 2007; Leitao-Faustino 2010).

The rapid growth of OFDI from emerging and developing countries resulted in numerous studies trying to account for special features of emerging multinationals (MNCs) behavior that is not captured within mainstream theories. For example, Mathews extended OLI paradigm with linking, leverage, learning framework (LLL) that explains rapid international expansion of companies ("Dragon multinationals") from Asia Pacific (Mathews 2006), while Dunning and Lundan extended the OLI model with the institution-based location advantages which explains that institutions developed at home and host economies shape the geographical scope and organizational effectiveness of MNCs (Dunning and Lundan, 2008). A further extension of the OLI framework with a fourth pillar was made by Kalotay-Sulstarova (2002). This pillar is a "H" which means a home country factor, referring mostly to state help and ownership. This was tested mostly on Russian multinationals (Kalotay et al. 2015) but can be highly relevant for Chinese ones too.

The activity of multinational companies is strongly apparent in trade. Fragmentation of production has increased to a considerable extent in the last decade, mostly in the electronic, clothing and automotive industry ${ }^{2}$ (Lall et al. 2004, Kimura et al. 2005, Vogiatzoglou 2012). International trade in such global production networks has risen much faster then "normal" trade. According to the report of UNCTAD (2013) 80 per cent of global trade (gross exports) is linked to the production network of multinational companies.

As a consequence, economic theories and literature on global production chains (or vertical specialisation, fragmentation of production, global value chains) proliferated. Knowing the distinction of the various notions, we will use the term global value chain (GVC) in this article. There are several streams of the GVC theories. One part of the literature explains their development and role for connecting developing economies (Baldwin 2012, Gereffi 2013 and others) other part deals with the governance of GVCs (Gereffi 2005, Lee-Gereffi 2014), another part focuses on upgrading within GVCs and its forms (Humphrey-Schmitz 2002, Cattaneo et al. 2013, Barrientos et al. 2010, Milberg-Winkler 2011) and yet another part with the measurement of their activity

\footnotetext{
2 The intensity of production fragmentation depends on certain factors like technically separable stages, factor intensity, the technological complexity of production and the weight of the product (transportable to large distances).
} 
especially in trade. The "trade in value-added" concept has been introduced and large databases were developed based on input-output tables of countries (Foster et al. 2013, Timmer et al. 2014, Koopman et al. 2014).

GVCs have an effect on trade theories too, the concept of revealed comparative advantage and real effective exchange rates for example have lost from their explanataory power. The country of origin concept has also become difficult to apply in trade policy. Based on trade data a country may appear to be a large exporter of a specific good relative to the world average without having contributed much value added to its production (Amador - di Mauro 2015). Beltramello et al. (2012) also show that the dominant role of GVCs questions export based competition indices, because export specialisation (for example to higher technology goods) is often based on high import content. Therefore real technological development, innovative activity behind the export of high-tech products is questionable or non existent. Countries with low $R \& D$ activities also show high shares of high-tech products in their exports and this is characteristic for several low income Asian countries (Srholec 2005). ${ }^{3}$ The import content of Chinese high-tech exports increased radically (IMF 2012). China itself became in the meantime an assembly country too. (The increasing role of China in the global network of information, communication and technology industry is proven by Amighimi (2005)). Cross-border movement of parts and products within the same production network increases the trade of countries, "artificially" generating international trade with each crossing.

During the transition to market economy, CEE countries went through radical economic changes. These changes had been largely induced by foreign capital. Foreign multinationals realised significant investment projects in this region and established their own production networks. This development path of the CEE countries served as an example for the "dependent market economy model" created by Nölke-Vliegenthardt (2009) The integration of several CEE countries into the global production chains and the drastic changes in production structure since the late 1990s were generally proven by others (Rahman-Zhao 2013, Timmer et al. 2012). Damijan et al. (2013) also concludes that inflow of FDI contributed significantly to the export restructuring of Central and Eastern European countries, but there are differences among countries.

There have been only a few comprehensive researches focusing on relations between China and Central and Eastern Europe so far. Despite the recent change in the relations, the number and depth of available international scientific publications and other resources are limited. Majority of these publications (Song 2013, Éltetö-

$3 \quad$ Participation in these global production networks means producing the labour intensive phases of high-tech intensive production (Srholec 2005). As a consequence of the increased fragmentation of production the assembly of an electronic product or a part can be similarly intensive in cheap labour as the assembly of any other machine. 
Szunomár 2015; Matura 2013; etc.) deal with political and/or economic relations of China and Central and Eastern Europe in general, while others focus more on investment issues between China and CEE countries (such as Woon 2003; Jacoby 2014; Liu 2014; Szunomár-Völgyi-Matura 2014) or trade relations (Éltető-Völgyi 2013).

Tuszynski (2015) describes the Polish role in the large CEE area -China cooperation briefly touching Chinese investment and trade with Poland. The article also shows the attitude of some CEE countries towards China. Pencea-Oehler-Sincai (2015) analyses Romanian trade and investment relations with China pointing to the increasing significance of bilateral relations. In a recent book, edited by Szunomár (2014) scholars from the Visegrad countries (V4) analyzed Chinese investments in Visegrad countries before and after the crisis with a special focus on Chinese investment. In addition to economic issues and intents, the authors examined the underlying political interests of both sides as well as the attitude of V4 societies to incoming Chinese capital and growing influence.

Éltetö-Toporowski (2013) give detailed analysis of the trade between the Visegrád countries and Asian regions between 2000 and 2012. Applying detailed product classification, they find high geographic and product concentration and changing product specialisation of Visegrád countries towards Asian countries. Based on these, they conclude that the integration of V4 countries into the global value chains of multinational companies is also apparent in their trade with Asia.

Ando and Kimura (2013) analyse the trade and production contacts between Asia and Europe via the Central European countries. They show that in the past 15 years the $\mathrm{CE}$ region increasingly connects the two continents in three ways: First, due to the dominance of East Asia in the electronics industry, European multinationals have been importing electronic parts and components from their Asian affiliates and other Asian firms to use them for their production in the CE region. Second, the automotive industry agglomerations in the CE import machinery parts and components from Asia. Third, certain Asian firms themselves have invested in the CE countries and intensified sourcing from Asia. These factors have resulted in tight production links between East Asia and Central Europe to serve the European market.

\section{Investment relations}

\section{Changing patterns and motivations of Chinese investment}

In hand with the "Open Door" policy reforms, the Chinese government encouraged the country's investment abroad to integrate China to the global economy, although the only entities allowed to invest abroad were state-owned enterprises (SOEs). The total investment of these first years of this new policy was not significant and concentrated to the neighbouring countries, mainly to Hong Kong. The regulations were liberalized after 1985 and a wider range of enterprises - including private firms - was permitted to invest abroad. After 1992 (the year when Deng Xiaoping made his Southern China 
tour), overseas investment increased dramatically, Chinese companies established overseas divisions almost all over the world, concentrated mainly in natural resources. Nevertheless, according to UNCTADstat, Chinese OFDI averaged only 453 million US dollars per year between 1982 and 1989 and 2.3 billion between 1990 and 1999 .

In 2000, before joining the World Trade Organization (WTO), the Chinese government initiated the "go global" ("zou chu qu") policy, which was aimed to encourage domestic companies to become globally competitive. They introduced new policies to induce firms to engage in overseas activities in specific industries, notably in trade-related activities. In 2001 this encouragement was integrated and formalized within the 10th five-year plan, which also echoed the importance of the go global policy (Buckley et al 2008). This policy shift was part of the continuing reform and liberalization of the Chinese economy and also reflected Chinese government's desire to create internationally competitive and well-known companies and brands. Both the 11th and 12nd five-year plan stressed again the importance of promoting and expanding OFDI, which became one of the main elements of China's new development strategy.

As recently the Chinese economy is facing new challenges and its economic strategy is transforming, the country's global investment position is altering as well, however, a bit more than a decade ago the amount of Chinese OFDI was almost negligible. Both Chinese OFDI flow and stock have steadily increased in the last decade (see Figures 1 and 2), particularly after 2008, due to the above mentioned policy shift and the changes in global economic conditions, that is, the global economic and financial crisis. The crisis brought more overseas opportunities to Chinese companies to raise their share in the world economy as the number of ailing or financially distressed firms has increased.

Figure 1 China's outward FDI flows at current prices, 1985-2013

120000

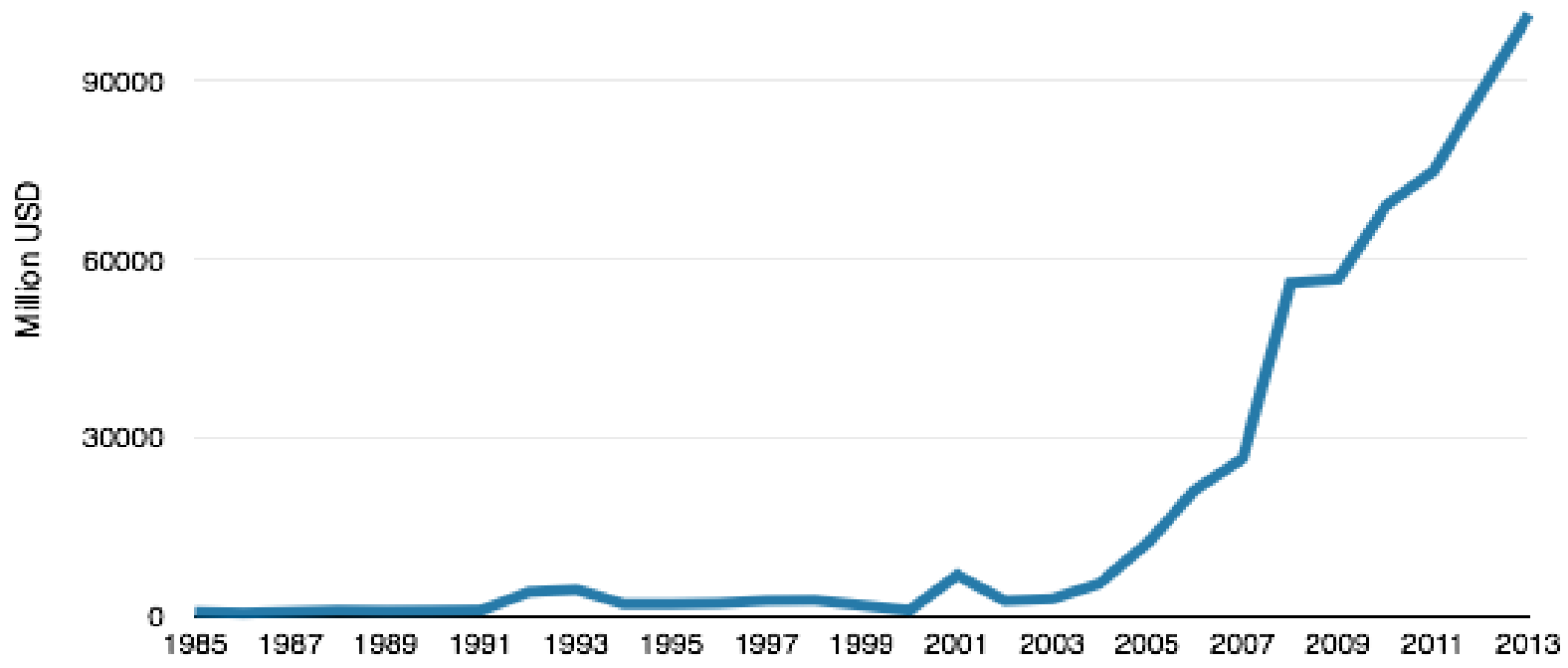

Data source: UNCTADStat 
Figure 2. Chinese outward FDI stock at current prices, 1985-2013

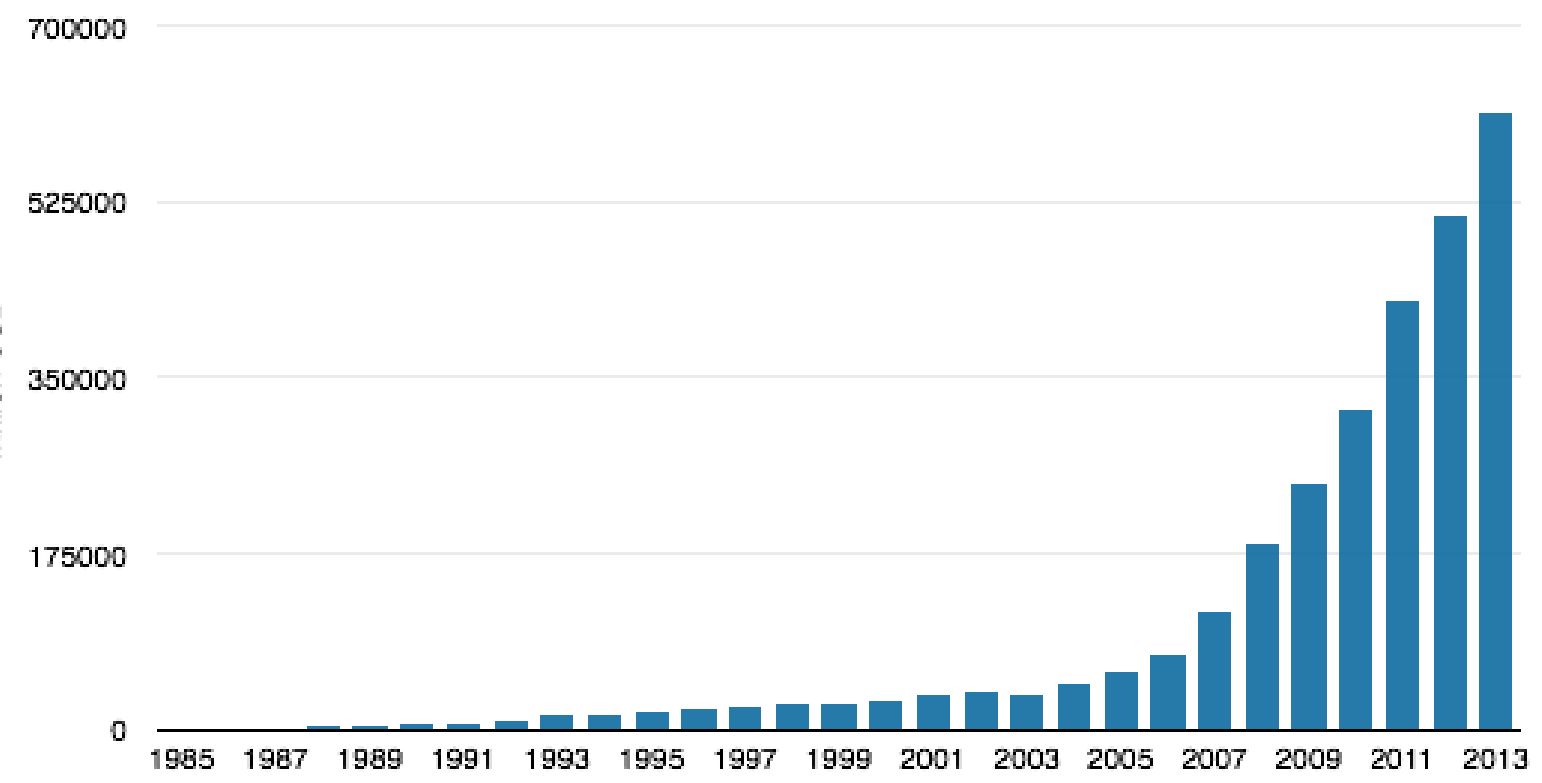

Data source: UNCTADStat

While OFDI from the developed world decreased in several countries because of the recent global financial crisis, Chinese outward investments increased even more: between 2007 and 2011, OFDI from developed countries dropped by 32 per cent, while China's grew by 189 per cent (He and Wang, 2014, p. 4; UNCTAD 2012). As a consequence, according to the World Investment Report 2013, China moved up from the sixth to the third largest investor in 2012, in the ranks of top investors after the United States and Japan. Among developing countries China was the largest investor - as outward investment continued to grow, reaching a record level of 84 billion US dollars in 2012.

Being one of the top investors of the developing world, since 2008 Chinese investment increased substantially in developed economies as well. Although this increase is impressive by all means, China still accounts for only $7 \%$ of total FDI inflows into the EU and $5 \%$ to the US (see Figure 3). However, analysing the actual final destination of Chinese OFDI, Wang found that - as a result of round-tripping investments developed countries receive more Chinese investments than developing economies: 60 per cent of Chinese ODI went to developed economies like Australia, Hong Kong, the United States, Germany, and Canada (Wang, 2013). 
Figure 3 Geographical distribution of Chinese OFDI stock, 2012

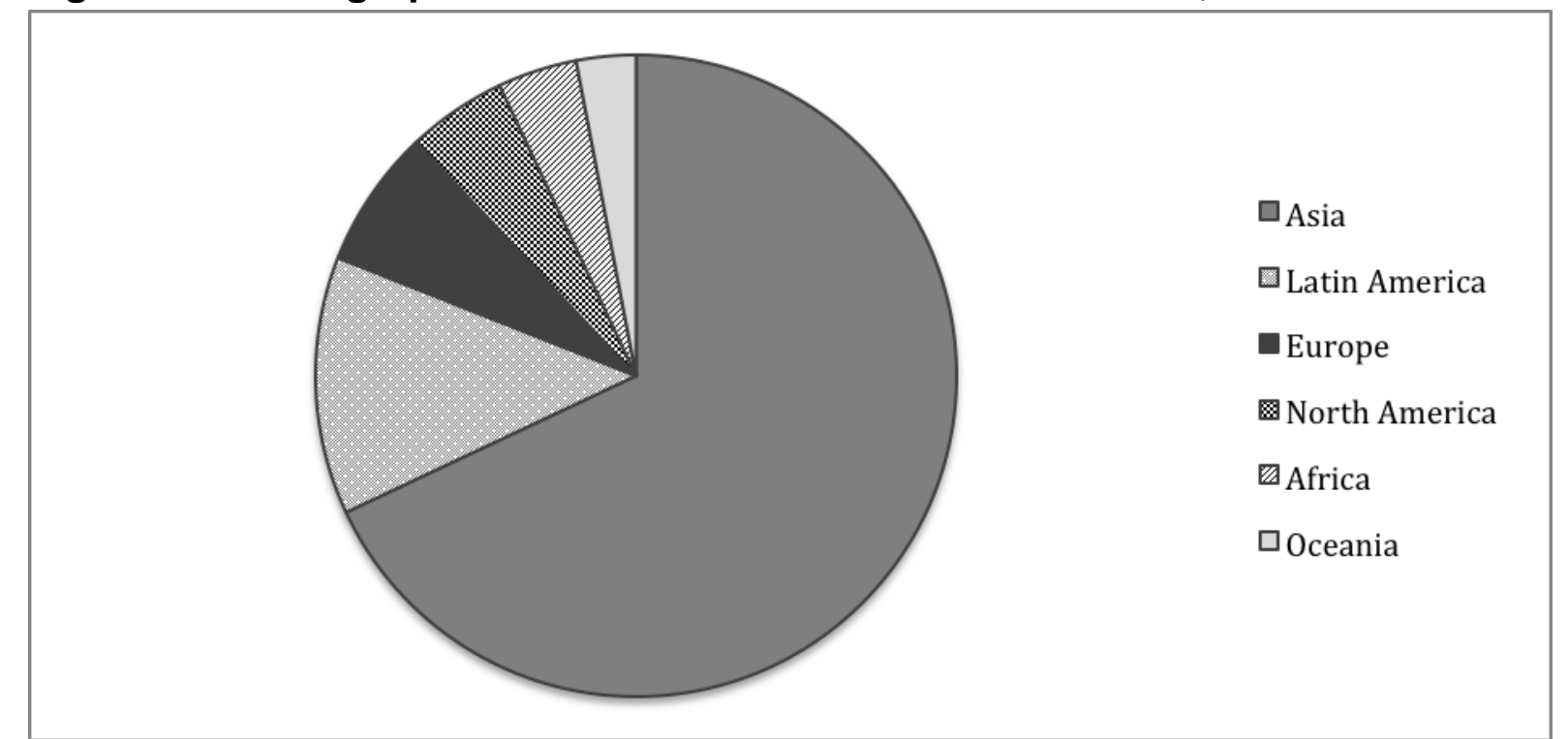

Source of chart data: MOFCOM and BBVA Research (BBVA, 2013, pp. 6-7)

As Clegg and Voss note, the industry-by-country distribution of Chinese OFDI is difficult to determine from Chinese statistics. However, based on their findings, it can be stated that Chinese investments in mining industry are taking place mainly in institutionally weak and unstable countries with large amounts of natural resources and that these investments are normally carried out by SOEs. Investments in manufacturing usually take place in large markets with low factor costs, while Chinese companies seek technologies, brands, distribution channels and other strategic assets in institutionally developed and stable economies (Clegg and Voss 2012, p. 19).

In developed economies Chinese investment is less dominated by natural resource seeking or trade-related motives but more concerned with the wide range of objectives, including market-, efficiency- and strategic assets-seeking motives (Rosen and Hanemann 2013, p. 69 and WIR p. 46). In the case of developed countries, Chinese SOEs usually have the majority of deal value but non-state firms make the greater share of deals (Rosen and Hanemann 2013, p. 71). In addition to greenfield investments and joint ventures, China's merger and acquisition (M\&A) activity in developed countries has recently gained a momentum and continue an upward trend since more and more Chinese firms are interested in buying overseas brands to strengthen their own. However, some attempted Chinese acquisitions failed in the United States and Australia in recent years (Davies 2013, p. 36).

Overall, Chinese outward investment is a result of a deliberate government policy. State help and state owned enterprises are crutial factors explaining Chinese OFDI. It is already discussed recently (Kalotay-Sulstarova 2010) that state-owned firms possess advantages that facilitate their internationalization (financial and administrative support). This can also be extended to privately owned firms whose international expansion is seen by the State as strategic priority and as a consequence, it is supported by all available means. 
Chinese investments in Central and Eastern Europe - facts and trends

As the concept of Central and Eastern Europe is broad, it would be too complicated and extensive to conduct a research on the relations of all countries of the region with China. Therefore we decided to focus our work on a selection of CEE countries, considering their size, position and relation to China. Bulgaria, the Czech Republic, Hungary, Poland, Romania, and Slovakia are among the most developed and most important players of the regions. Although these six countries differ in many respects, they have some common features as well. They have been in the process of economic catching up over the last decades, their development paths are defined mainly by the global and European powers, rules and trends and FDI has a key role in restructuring of these economies. Most of the above mentioned countries started to get more interested in attracting Chinese investments and boosting trade relations since the new millennium. However, the economic and financial crisis of 2008 drew the attention of these five countries more than ever to the potential of Chinese economic relationship (McCaleb-Szunomár 2014).

\section{Figure 4 China's OFDI stock in CEEC, 2003-2013, Selected Countries}

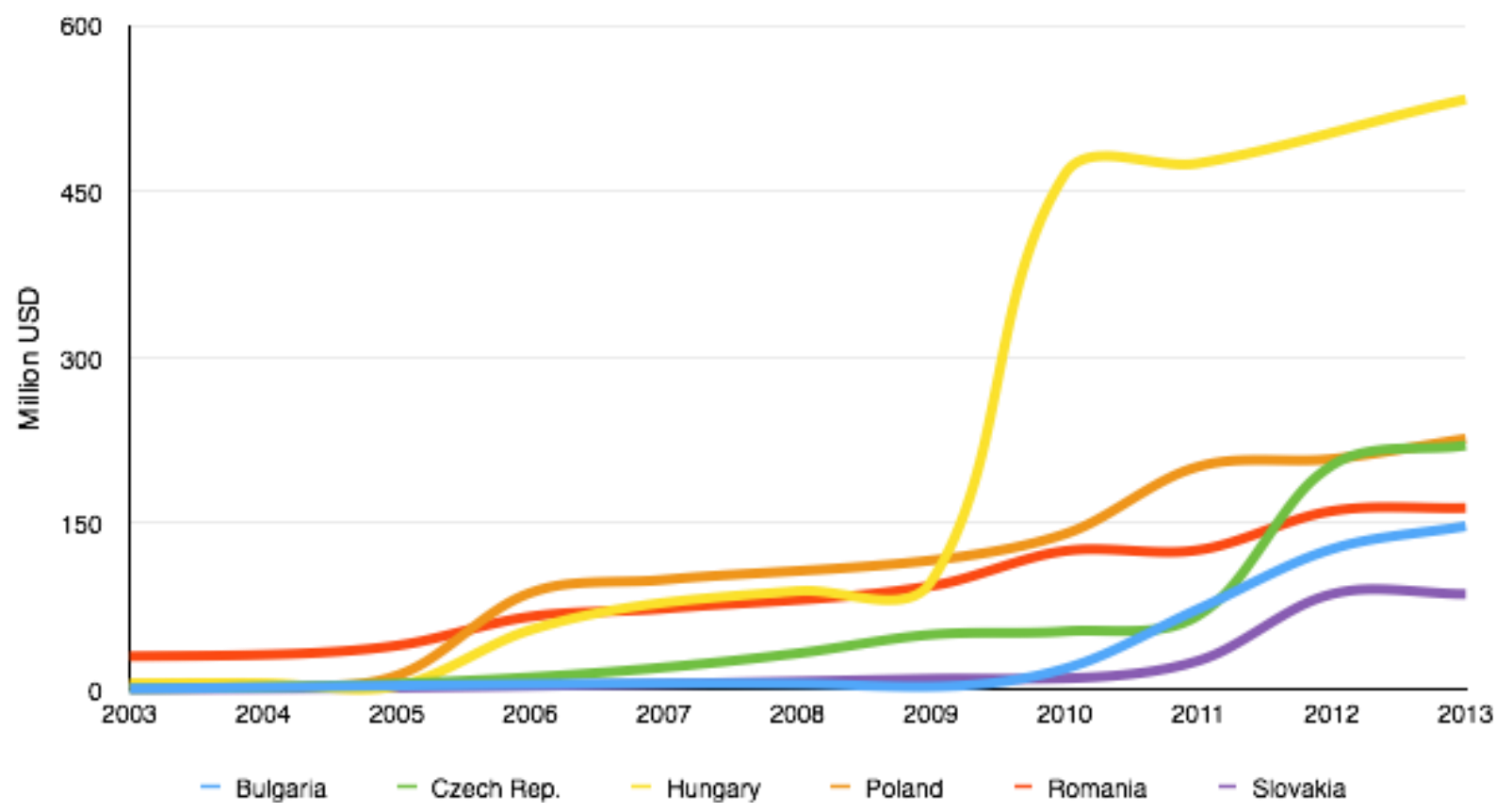

Source: MOFCOM/NBS 2013, in the case of Slovakia MOFCOM/NBS 2012

The role of Chinese capital in Central and Eastern Europe, compared with all the invested capital is still very small, but in the last few years this capital inflow accelerated significantly and also played (and plays) an important role in the region's recovery from the crisis. In the case of the selected countries there is a growing demand for attracting Chinese companies in the last two to five years. The exception is Hungary where this process has already begun earlier, after 2003. 
When searching for possible factors that make the region a favourable investment destination for China, the cost and quality of labour is to be considered first: a skilled labour force is available in sectors for which Chinese interest is growing, while labour costs are lower in the CEE region than the EU average. However, there are differences within the region as well; unit labour costs are cheaper in Bulgaria and Romania than in Hungary, Czech Republic, Slovakia and Poland. These differences don't seem to really influence Chinese investors as there is more investment in Hungary and Poland than in Romania and Bulgaria, however, an explanation for that can be the theory of agglomeration effect as generally OFDI in these countries is the highest in the region (McCaleb-Szunomár 2014).

Considering the motivation of Chinese investments in CEE, the change of the institutional setting of CEE countries due to their economic integration into the EU has been the most important driver that has spurred Chinese FDI in the region, especially in the manufacturing sector. EU membership of the V4 countries allowed Chinese investors to avoid trade barriers and the countries served as an assembly base due to the relatively low labour costs (efficiency-seeking, see McCaleb- Szunomár 2014). The main type of Chinese FDI in the selected countries is thus market-seeking investment: by entering CEE markets Chinese companies have access not only to EU market but also to markets of CIS, Mediterranean, EFTA. Another aspect of EU membership that has induced Chinese investment in CEECs is institutional stability (e.g., protection of property rights) as one of the drivers of Chinese OFDI is unstable institutional, economic and political environment of their home country (e.g., Morck et al. 2007). It is in line with the findings of Clegg and Voss $(2011,101)$ who argue that Chinese OFDI in the EU shows "an institutional arbitrage strategy".

Chinese investors typically target secondary and tertiary sectors of the CEE countries. Initially, Chinese investment has flowed mostly into manufacturing (assembly), but over time services attracted more and more investment too, for example in Hungary and Poland there are branches of Bank of China and Industrial and Commercial Bank of China as well as offices of some of the largest law offices in China, Yingke Law Firm (in Hungary in 2010, in Poland in 2012), Dacheng Law Offices (in Poland in 2011, in Hungary in 2012). Main Chinese investors targeting these countries are interested primarily in telecommunication, electronics, chemical industry, transportation and energy markets. Their investments are motivated by seeking of brands, new technologies or market niches that they can fill in on European markets (McCaleb-Szunomár 2014).

According to McCaleb and Szunomár (2014), we can find several examples of statelevel incentives. Since the aftermath of the global financial crisis we can observe increased interest of the CEECs governments in attracting Chinese investors. For example, Poland started actively promoting itself with Chinese firms since the EXPO 2010 in Shanghai. Since 2010 Polish Information and Foreign Investment Agency (PAIZ) has its website available in Chinese, in 2011 it set up its overseas office in 
Shanghai and in 2013, PAIZ launched website GoPoland.gov.pl in Chinese with the goal of attracting Chinese investors to Poland. However, in most of the analyzed countries there are voices complaining about their governments' lack of unified strategy towards Chinese investors. Hungary is an exception in this respect as it has had historically good political relations with China and earlier than other CEECs, intensified bilateral relations in order to attract Chinese FDI. Hungary introduced special incentive for foreign investors from outside the EU: a possibility to receive a residence visa when fulfilling the requirement of a certain level of investment in Hungary 4 . Moreover, Hungary has the largest Chinese diaspora in the region which is an acknowledged attracting factor of Chinese FDI in the extant literature that is a relational asset constituting firm's ownership advantage (e.g., Buckley et al. 2007).

\section{Country-level analysis 5}

As mentioned, the selected six countries give the majority of the population and the economic output of the CEE region, and all of them have strengthened their relation with China in recent years. Table 1 shows the main features of Chinese investment in these economies.

\footnotetext{
$4 \quad$ Third country nationals are allowed to acquire Hungary's permanent residency status through investing in Special Hungarian Government Bonds that have a minimum 5-year maturity. The minimum initial investment by each subscriber is 250,000 EUR.

$5 \quad$ This section is based on the paper of McCaleb A., Szunomár Á. (2014): Chinese foreign direct investment in Central and Eastern Europe: an institutional perspective. Unpublished manuscript.
} 
Table 1. Characteristics of Chinese FDI in CEE-6 countries

\begin{tabular}{|c|c|c|c|c|c|c|}
\hline & Hungary & Poland & $\begin{array}{l}\text { Czech } \\
\text { Republic }\end{array}$ & Slovakia & Bulgaria & Romania \\
\hline $\begin{array}{l}\text { FDI stock } \\
\text { (USD, } \\
2013 \text { ) }\end{array}$ & 533 million & 226 million & 220 million & 90 million & 147 million & 164 million \\
\hline $\begin{array}{l}\text { Main } \\
\text { form of } \\
\text { investme } \\
\text { nt }\end{array}$ & $\begin{array}{l}\text { Greenfield / } \\
\text { brownfield, } \\
\text { M\&A, joint } \\
\text { ventures }\end{array}$ & $\begin{array}{l}\text { Greenfield, } \\
(M \& A)\end{array}$ & $\begin{array}{l}\text { Greenfield } \\
,(M \& A)\end{array}$ & Greenfield & Greenfield & Greenfield \\
\hline $\begin{array}{l}\text { Main } \\
\text { sectors }\end{array}$ & $\begin{array}{l}\text { Chemical, } \\
\text { IT / ICT, } \\
\text { electronics, } \\
\text { wholesales } \\
\text { and retails, } \\
\text { banking, } \\
\text { hotels and } \\
\text { catering, } \\
\text { logistics, } \\
\text { real estate }\end{array}$ & $\begin{array}{l}\text { IT / ICT, } \\
\text { electronics, } \\
\text { heavy } \\
\text { machinery, } \\
\text { publishing } \\
\text { and } \\
\text { printing, } \\
\text { real estate }\end{array}$ & $\begin{array}{l}\text { Electronic } \\
\text { s, IT / ICT, } \\
\text { transport } \\
\text { equipment } \\
\text {, food, } \\
\text { media, } \\
\text { aviation }\end{array}$ & $\begin{array}{l}\text { automotiv } \\
\text { e industry, } \\
\text { IT / ICT }\end{array}$ & $\begin{array}{l}\text { IT / ICT, } \\
\text { television, } \\
\text { agriculture } \\
\text { machinery }\end{array}$ & $\begin{array}{l}\text { ICT / IT, } \\
\text { tobacco, } \\
\text { agriculture, } \\
\text { machinery, } \\
\text { transportati } \\
\text { on }\end{array}$ \\
\hline $\begin{array}{l}\text { Most } \\
\text { important } \\
\text { Chinese } \\
\text { compani } \\
\text { es }\end{array}$ & $\begin{array}{l}\text { Wanhua, } \\
\text { Huawei, } \\
\text { ZTE, } \\
\text { Lenovo, } \\
\text { Sevenstar } \\
\text { Electronics, } \\
\text { BYD } \\
\text { Electronics, } \\
\text { Comlink }\end{array}$ & $\begin{array}{l}\text { LiuGong } \\
\text { Machinery, } \\
\text { Haoneng } \\
\text { Packaging, } \\
\text { Shanxi } \\
\text { Yuncheng } \\
\text { Plate- } \\
\text { making } \\
\text { Group, Sino } \\
\text { Frontier } \\
\text { Properties } \\
\text { Ltd. }\end{array}$ & $\begin{array}{l}\text { Shanxi } \\
\text { Yuncheng, } \\
\text { Changhon } \\
\text { g, Noark, } \\
\text { Huawei, } \\
\text { ZTE, } \\
\text { Shanghai } \\
\text { Maling }\end{array}$ & $\begin{array}{l}\text { SaarGum } \\
\text { mi, ZVL } \\
\text { Auto, } \\
\text { Inalfa } \\
\text { Roof } \\
\text { Systems, } \\
\text { Mesnac, } \\
\text { Lenovo, } \\
\text { Huawei }\end{array}$ & $\begin{array}{l}\text { Huawei, } \\
\text { ZTE, } \\
\text { Shanghai } \\
\text { Video and } \\
\text { Audio } \\
\text { Electronic } \\
\text { s, Great } \\
\text { Wall } \\
\text { Motors, } \\
\text { Tianjin } \\
\text { State } \\
\text { Farms, } \\
\text { Insigma } \\
\text { Tech. }\end{array}$ & $\begin{array}{l}\text { Huawei, } \\
\text { ZTE, } \\
\text { Shantuo } \\
\text { Agricultural } \\
\text { Machinery } \\
\text { Equipment, } \\
\text { China } \\
\text { Tobacco, } \\
\text { China } \\
\text { Shipping, } \\
\text { COSCO, } \\
\text { Shanxi } \\
\text { Yuncheng, }\end{array}$ \\
\hline
\end{tabular}

Chinese investment to Hungary started to increase significantly after the country joined the EU in 2004. According to Chinese statistics, it means a real rapid increase from 0.65 million US dollars in 2005 to 370.1 million US dollars in 2010. In 2010, Hungary itself took $89 \%$ of the whole Chinese capital flow to the region (Chen, 2012). By 2013, the amount of Chinese investments has further increased and reached 533 million USD according to MOFCOM data, which is by far the highest in the region. Nevertheless, this amount is far greater when taking cumulative Hungarian data into account, since a significant portion of Chinese investment is received via intermediary countries or companies, therefore it appears elsewhere in Chinese statistics. According to Hungarian reports (cumulative data), Chinese investment in Hungary was about 3 billion USD by 2014. More than 1.5 billion USD from that is the investment of the Chinese chemical company Wanhua, which acquired a 96 per cent 
stake in the Hungarian chemical company BorsodChem through its Dutch subsidiary in 2010 and 2011. This subsidiary also made some investment for the development of BorsodChem later. It is the largest Chinese investment in CEE so far. Although Chinese multinational companies represent a relatively small share of total FDI stock in Hungary, they have saved and/or created jobs and contributed to the economic growth of Hungary with their investments and exports during the crisis. Furthermore, many of them (e.g. Lenovo, ZTE, Huawei, Bank of China) have turned their Hungarian businesses into the European regional hub of their activities (Szunomár et al., 2014).

Although Poland is the leading recipient of FDI in the CEE region it attracted less Chinese FDI than Hungary. Before Poland's entry into the EU Chinese investments were almost insignificant as in 2000 they amounted to 10 USD million and in 2003 increased slightly to 17.8 USD million6. According to Polish data, Chinese FDI stock in Poland increased more than sixteen times to 288.1 USD million by the end of 2012 . However their importance is low as they represent only $0.1 \%$ of Poland's total FDI stock. According to MOFCOM, China's FDI stock in Poland amounted to 226 USD million at the end of 2013, however, as mentioned above, statistics on China's OFDI differ between MOFCOM's and host countries' national sources (Clegg and Voss 2012). In addition to intermediaries or subsidiaries these differences may result from limitations of Chinese data ${ }^{7}$

Czech Republic is also one of the most successful CEE countries in attracting foreign direct investment although Chinese investments were negligible till 2012. According to Chinese statistics Chinese FDI in Czech Republic started to increase from 2006 (in 2005 it was 1,38 million USD, compared with 14.67 million USD in 2006) and reached 66,83 million USD in 2011, which was still the lowest amount of the five selected countries. The turning point was 2012 when Chinese statistics showed 202,45 million USD investment to the Czech Republic ${ }^{8}$. However, there is an inverse discrepancy here as according to data from Czech National Bank, the Chinese FDI in Czech Republic was 76,6 million USD in $2012^{9}$. In 2013, according to Chinese data, Chinese FDI stock was 220 million USD.

The amount of Chinese investments was insignificant in Slovakia prior to 2007. From 2007 on we can observe varying levels of Chinese investments in the country. According to Turcsányi (2014, p. 97) "While little can be asserted due to large fluctuation, we can notice the start of the investments even before the crisis. Consequently, the investments increased, yet it is difficult to establish whether this

\footnotetext{
${ }^{6}$ National Bank of Poland data

MOFCOM data are underreported as they include investments approved by MOFCOM. Thus, in practice investment projects (especially small projects) that do not require approval or unauthorized projects are not included. The recent administrative reforms decentralized approval system of smaller investment projects which may enhance under-reporting.

$8 \quad$ Total FDI to Czech Republic was 10,6 billion USD according to UNCTAD.

$9 \quad$ The official statistics explain this huge increase with the recalculation of stock for 2012 after adjustment of historical data. Experts in Czech Republic had no information on the components of this growth.
} 
was the result of the crisis or some other factors, which may include natural development of Chinese investors' increasingly available source and willingness to penetrate new destinations." According to Chinese statistics Chinese OFDI stock in Slovakia was a bit below 90 million USD in 2012 (data from 2013 was no available). The definite number of Chinese investment is hard to tell, but according to available sources it can be established that it is relatively modest - compared both to neighbouring countries and to other investors in Slovakia, including other Asian companies. According to Turcsányi's estimates (2014, p. 98), "in case also companies owned by a non-Chinese based but Chinese-owned subsidiary are counted, we can estimate current Chinese investments in Slovakia to be up to 100-200 million EUR."

Chinese FDI in Romania was the highest among all CEECs until $2005^{10}$, now according to Chinese statistics - Romania is only the fourth largest recipient in CEECs after Hungary, Poland and Czech Republic with Chinese FDI worth of 163,8 million USD. Chinese FDI in Bulgaria started to become noticeable from 2007 when Bulgaria joined the EU. According to Chinese data, it increased seven-fold from 18,6 million USD in 2010 to 147,4 million in 2013.

\section{Trade with China}

Certainly, the European Union has a dominant role in the trade of the CEE countries. The share of Asian countries is much less, but their role has increased during the past years (Éltetö-Szunomár 2014). Trade increase towards Asia has been more dynamic than towards the EU or towards non-EU regions (Éltetö-Toporowski 2013). The weight of Asia is generally more significant in imports than in exports of CEE 6 countries (Table 2). ${ }^{11}$ Trade dynamism is largely due to the trade with China, that has become the most important partner within Asia. Between 2000-2014 China's share increased in the export of CEE- 6 but the increase is even more significant in their import. In the case of the Czech Republic, Hungary and Slovakia around 6\% of their import stems from China, while for Slovakia, Romania, Bulgaria this share is around $4 \%$.

\footnotetext{
10 In 2005, Chinese investment was 39,43 million USD in Romania according to Chinese statistics, which further increased in the coming years, but to a lesser extent compared to Hungary and Poland.

${ }^{11}$ An exception is Bulgaria where Asia has more than $10 \%$ share in total exports. This (and the relatively high Romanian figures also) is due to the deliveries of petroleum oil products to Singapore, the Middle East and CIS area performed by the Bulgarian and Romanian refineries of Russian Lukoil company.
} 
Table 2 Share of EU, Asia and China in the foreign trade of the CEE- 6 countries

\begin{tabular}{|l|c|c|c|c|c|c|c|c|c|c|c|c|}
\hline & \multicolumn{4}{|c|}{ EU } & \multicolumn{4}{c|}{ Asia } & \multicolumn{3}{c|}{ China } \\
\hline & \multicolumn{2}{|c|}{ Export } & \multicolumn{2}{|c|}{ Import } & \multicolumn{2}{c|}{ Export } & \multicolumn{2}{c|}{ Import } & \multicolumn{2}{c|}{ Export } & \multicolumn{2}{c|}{ Import } \\
\hline & $\mathbf{2 0 0 0}$ & $\mathbf{2 0 1 4}$ & $\mathbf{2 0 0 0}$ & $\mathbf{2 0 1 4}$ & $\mathbf{2 0 0 0}$ & $\mathbf{2 0 1 4}$ & $\mathbf{2 0 0 0}$ & $\mathbf{2 0 1 4}$ & $\mathbf{2 0 0 0}$ & $\mathbf{2 0 1 4}$ & $\mathbf{2 0 0 0}$ & $\mathbf{2 0 1 4}$ \\
\hline $\begin{array}{l}\text { Czech } \\
\text { Republic }\end{array}$ & 85.9 & 81.8 & 75.2 & 77.1 & 4.0 & 5.2 & 8.2 & 13.9 & 0.2 & 1.2 & 2.2 & 6.2 \\
\hline Hungary & 83.6 & 78.4 & 66.1 & 74.3 & 3.4 & 4.8 & 16.8 & 11.8 & 0.1 & 1.7 & 2.9 & 6.3 \\
\hline Poland & 81.2 & 76.8 & 69.0 & 69.0 & 3.4 & 4.9 & 10.5 & 12.3 & 0.3 & 1.0 & 2.8 & 6.4 \\
& & & & & & & & & & & & \\
\hline Slovakia & 89.8 & 83.9 & 70.2 & 75.8 & 1.8 & 3.9 & 5.7 & 12.4 & 0.1 & 2.1 & 1.4 & 4.0 \\
\hline Romania & 72.2 & 70.8 & 65.3 & 75.2 & 6.4 & 6.8 & 9.0 & 10.9 & 0.8 & 1.1 & 1.3 & 4.0 \\
\hline Bulgaria & 56.2 & 62.1 & 52.9 & 61.4 & 6.2 & 11.6 & 5.3 & 7.9 & 0.8 & 2.4 & 1.0 & 3.3 \\
\hline
\end{tabular}

Source: calculations from Eurostat Comext

Figure 5 shows trade figures for eleven Central and East European countries. Five CEE countries (the Baltic countries and Slovenia, Croatia) have quite low trade with China. Within the whole CEE region the four Visegrad countries show the highest trade flows, followed by Romania and Bulgaria. Therefore we focus on the trade patterns of these six countries (CEE-6).

Figure 5. Trade with China in 2014, mn euros

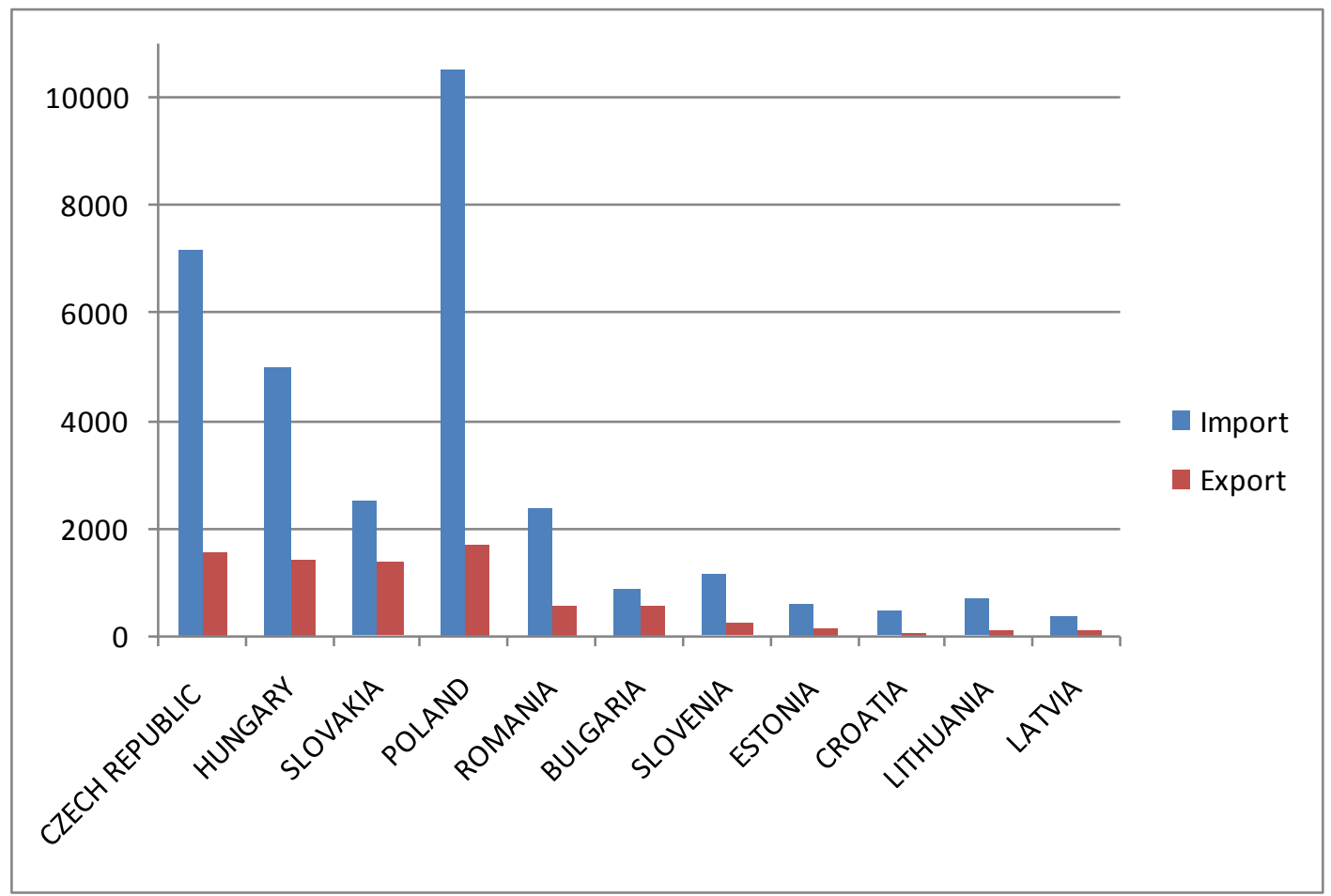

Source: Eurostat Comext 
A common feature of CEE trade with China is the considerable deficit that is present in every country. Poland as the largest country has the highest deficit among all. This deficit has had a constant increasing trend in the past fifteen years for the CEE countries, only in the case of Hungary and the Czech Republic can we observe a decrease since 2010-2011.

The mentioned dynamic increase of CEE-6 export to China is shown by Figure 6 . Two groups of countries can be clearly distinguished: the four Visegrad countries and Romania-Bulgaria. In case of the V4 export increase is radical from 2003 onwards, reaching similar level in 2013. The trend is broken in 2014 for Slovakia and Hungary but continues for Poland and the Czech Republic. In the case of Romania and Bulgaria, the increase takes place from 2009, most probably as a consequence of the crisis (searching for new markets outside the EU). Otherwise, for all six countries the upward trend was not even broken by the general world trade collapse in 2009.

Figure 6. Development of CEE-6 exports to China, mn euro

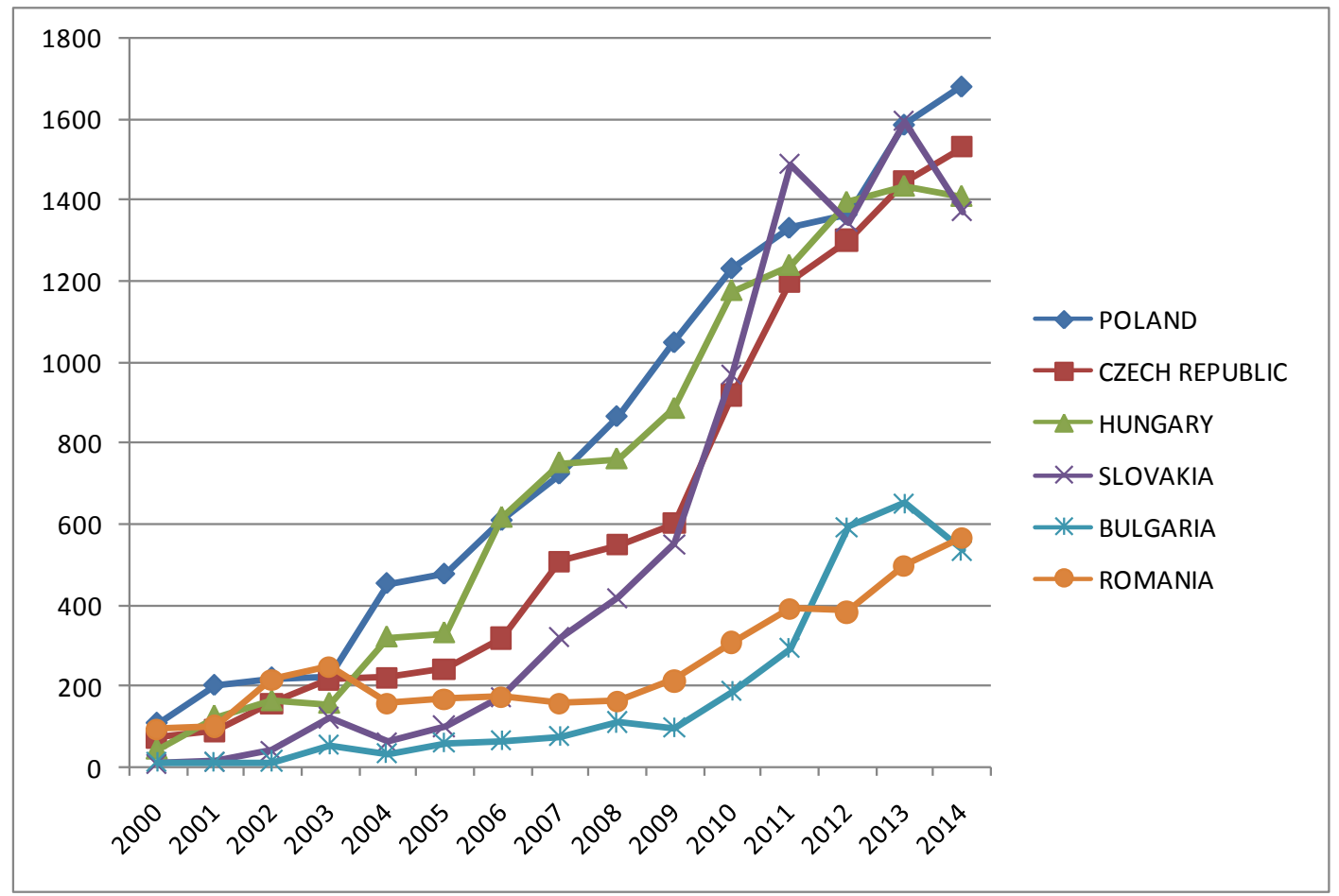

Source: Eurostat Comext

\section{Traded products}

Applying the more detailed product classification of SITC 3 we calculated the shares of the first five product groups in the given countries' trade. (This classification contains almost 300 product groups). In most cases we find high concentration of trade. The most extreme case is of Slovakia, where more than $70 \%$ of exports to China are given by one group: motor cars (see Table 3). ${ }^{12}$ However, in 2014-15

12The most popular cars exported from Slovakia to China are the Audi Q7 and the Volkswagen Touareg. In 2012 the territorial dispute between China and Japan over the Senkaku Islands was an 
Chinese demand for luxury cars stagnated or decreased and this has affected the Slovakian export performance ${ }^{13}$.

Hungarian exports are dominated by engines since the mid-2000 years, although their share in exports decreased from almost $50 \%$ in 2009 to $18 \%$ in 2014 . The reason for this decrease is that the Hungarian affiliate of the Volkswagen Group (Audi Hungaria) decreased its delivery of engines radically to the Chinese affiliate of the VW Group (FAW-Volkswagen, a joint venture between FAW Group and Volkswagen Group which manufactures Audi and Volkswagen passenger cars for sale in China). This decrease had an effect on the total Hungarian export to China.

Bulgarian export is also heavily concentrated (more than $50 \%$ ) to the same article that Poland delivers too (more than $30 \%$ ) that is copper. Although this is a raw material, it is a base material for producing integrated circuits and electronic parts, the key components of electronic devices produced in GVCs. Europe's second biggest copper producer is the Polish KGHM PolskaMiedź S.A. and closely cooperates with Chinese Minmetals. Thus, with this base material Poland and Bulgaria also participate in multinational networks, but in a lower, non-high-tech intensive level. Czech exports are the least concentrated and the main product group changed each year.

advantage for the Slovakian industry. Because of the conflict, the Chinese boycotted Japanese vehicles and turned to German models instead. Volkswagen produces the three big sports models which were in high demand in China: the Bratislava factory produces the VW Touareg and Audi Q7 models as well as the bodywork for the Porsche Cayenne (http://www.voxeurop.eu/en/content/newsbrief/2839471-china-and-japan-spat-provides-work-slovaks). Furthermore, the Volkswagen plant in Slovakia also began exports of Skoda cars to China in 2013 (http://www.automotivelogisticsmagazine.com/intelligence/vws-european-exports-to-china-will-stillgrow).

${ }^{13}$ http://www.ft.com/intl/cms/s/0/656ddbc8-4d63-11e5-9b5d-89a026fda5c9.html\#axzz3nOhkB8Qd 
Table 3. The most important export products to China, percentage of total export

\begin{tabular}{|c|c|c|c|c|c|}
\hline & 2000 & 2007 & 2009 & 2010 & 2014 \\
\hline & $\begin{array}{l}\text { AUTOMATIC } \\
\text { DATA- } \\
\text { PROCESSING } \\
\text { MACHINES }\end{array}$ & $\begin{array}{l}\text { INTERNAL } \\
\text { COMBUSTION } \\
\text { PISTON } \\
\text { ENGINES }\end{array}$ & $\begin{array}{l}\text { INTERNAL } \\
\text { COMBUSTIO } \\
\text { N PISTON } \\
\text { ENGINES }\end{array}$ & $\begin{array}{c}\text { INTERNAL } \\
\text { COMBUSTION } \\
\text { PISTON ENGINES }\end{array}$ & $\begin{array}{c}\text { INTERNAL } \\
\text { COMBUSTION } \\
\text { PISTON } \\
\text { ENGINES }\end{array}$ \\
\hline $\mathrm{HU}$ & 17,75 & 44,80 & 48,45 & 35,77 & 18,18 \\
\hline & $\begin{array}{c}\text { COPPER ORES } \\
\text { AND } \\
\text { CONCENTRAT } \\
\text { ES }\end{array}$ & COPPER & COPPER & COPPER & COPPER \\
\hline $\mathrm{BU}$ & 40,60 & 29,12 & 36,30 & 54,51 & 55,28 \\
\hline & $\begin{array}{l}\text { MOTOR CARS } \\
\text { AND OTHER } \\
\text { MOTOR } \\
\text { VEHICLES } \\
\end{array}$ & $\begin{array}{l}\text { PARTS AND } \\
\text { ACCESSORIES } \\
\text { of MACHINES }\end{array}$ & $\begin{array}{c}\text { TRANSMISSI } \\
\text { ON SHAFTS } \\
\text { GEARING }\end{array}$ & $\begin{array}{c}\text { PARTS AND } \\
\text { ACCESSORIES OF } \\
\text { MOTOR VEHICLES }\end{array}$ & $\begin{array}{l}\text { ELECTRICAL } \\
\text { APPARATUS } \\
\text { FOR } \\
\text { SWITCHING }\end{array}$ \\
\hline $\mathrm{CZ}$ & 22,75 & 10,20 & 8,40 & 8,21 & 11,45 \\
\hline & COPPER & COPPER & COPPER & COPPER & COPPER \\
\hline$P L$ & 46,37 & 29,89 & 34,11 & 36,93 & 31,48 \\
\hline & $\begin{array}{l}\text { WOOD, SIMPLY } \\
\text { WORKED, AND } \\
\text { RAILWAY } \\
\text { SLEEPERS OF } \\
\text { WOOD }\end{array}$ & $\begin{array}{l}\text { NON-FERROUS } \\
\text { BASE METAL } \\
\text { WASTE AND } \\
\text { SCRAP, N.E.S. }\end{array}$ & $\begin{array}{c}\text { NON- } \\
\text { FERROUS } \\
\text { BASE METAL } \\
\text { WASTE AND } \\
\text { SCRAP, } \\
\text { N.E.S. }\end{array}$ & $\begin{array}{c}\text { NON-FERROUS } \\
\text { BASE METAL WASTE } \\
\text { AND SCRAP, N.E.S. }\end{array}$ & $\begin{array}{l}\text { WOOD, SIMPLY } \\
\text { WORKED, AND } \\
\text { RAILWAY } \\
\text { SLEEPERS OF } \\
\text { WOOD }\end{array}$ \\
\hline $\mathrm{RO}$ & 34,95 & 29,80 & 18,86 & 17,05 & 12,61 \\
\hline & $\begin{array}{c}\text { OTHER } \\
\text { MACHINERY } \\
\text { AND } \\
\text { EQUIPMENT }\end{array}$ & $\begin{array}{l}\text { MOTOR CARS } \\
\text { AND OTHER } \\
\text { MOTOR } \\
\text { VEHICLES }\end{array}$ & $\begin{array}{c}\text { MOTOR } \\
\text { CARS AND } \\
\text { OTHER } \\
\text { MOTOR } \\
\text { VEHICLES }\end{array}$ & $\begin{array}{l}\text { MOTOR CARS AND } \\
\text { OTHER MOTOR } \\
\text { VEHICLES }\end{array}$ & $\begin{array}{c}\text { MOTOR CARS } \\
\text { AND OTHER } \\
\text { MOTOR } \\
\text { VEHICLES }\end{array}$ \\
\hline SK & 30,77 & 64,72 & 72,12 & 75,73 & 74,43 \\
\hline
\end{tabular}

Source: calculations from Eurostat

In the last two years the export of CEE agricultural products to China gained certain impetus. Chinese authorities usually undertake a long period of examination and allowance of these products into the Chinese market. Hungary recently received permission to export beef (although there is no significant delivery so far) and milk products (being third after Poland and Bulgaria) and more and more firms can export pork too. In the beginning of 2015 Chinese authorities approved import of Romanian frozen pork meat ${ }^{14}$. This is realised by Smithfield Romania SA, which was an affiliate of Smithfield large US global food company present in 13 countries. The Chinese WH Group acquired Smithfield in 2013. The Constanta port in Romania has strategic significance in trade, ${ }^{15}$ the biggest Chinese cereal trader firm even bought terminal there. ${ }^{16}$ Czech beer export increased significantly last year ${ }^{17}$ and it will increase

\footnotetext{
${ }^{14 h t t p: / / w w w . g l o b a l m e a t n e w s . c o m / I n d u s t r y-M a r k e t s / R o m a n i a-t o-r e l a u n c h-p o r k-e x p o r t s-t o-C h i n a ~}$

${ }^{15} \mathrm{http}: / /$ www.agerpres.ro/english/2014/10/30/romania-china-agrimins-pay-working-visit-to-constantaport-17-13-22

${ }^{16} \mathrm{http}: / /$ www.nineoclock.ro/china\%E2\%80\%99s-cofco-buys-cereal-terminal-in-constanta-port/
} 
further as the Chinese CEFC group bought majority share in the Czech Lobkowicz brewery. ${ }^{18}$

On the import side the leading products for several CEE-6 countries are telecommunication equipments (Table 4). These are the most significant in the Hungarian import from China, taking up 40-55 percent since years. Their weight is relatively significant in the Slovakian and Romanian and Czech import also. The least concentrated is the Bulgarian import, thus this pattern differs from the others. In general terms, for most CEE countries import from China dropped in 2009 due to the crisis, but afterwards gained momentum again.

Table 4. The most important import products from China, percentage of total export

\begin{tabular}{|c|c|c|c|c|c|}
\hline & 2000 & 2007 & 2009 & 2010 & 2014 \\
\hline & $\begin{array}{c}\text { ORGANO-INORGANIC } \\
\text { COMPOUNDS, } \\
\text { HETEROCYCLIC } \\
\text { COMPOUNDS, } \\
\text { NUCLEIC ACIDS AND } \\
\text { THEIR SALTS, AND } \\
\text { SULPHONAMIDES }\end{array}$ & $\begin{array}{l}\text { HEATING } \\
\text { AND } \\
\text { COOLING } \\
\text { EQUIPMENT } \\
\text { AND PARTS } \\
\text { THEREOF, } \\
\text { N.E.S. }\end{array}$ & $\begin{array}{c}\text { TELECOMMUNIC } \\
\text { ATIONS } \\
\text { EQUIPMENT }\end{array}$ & $\begin{array}{l}\text { TELECOMMU } \\
\text { NICATIONS } \\
\text { EQUIPMENT }\end{array}$ & $\begin{array}{l}\text { TELECOMMU } \\
\text { NICATIONS } \\
\text { EQUIPMENT }\end{array}$ \\
\hline $\mathrm{BU}$ & 9,08 & 7,48 & 5,00 & 5,51 & 4,02 \\
\hline & $\begin{array}{l}\text { AUTOMATIC DATA- } \\
\text { PROCESSING } \\
\text { MACHINES AND } \\
\text { UNITS. }\end{array}$ & $\begin{array}{c}\text { PARTS AND } \\
\text { ACCESSORI } \\
\text { ES } \\
\text { MACHINES }\end{array}$ & $\begin{array}{l}\text { PARTS AND } \\
\text { ACCESSORIES } \\
\text { MACHINES }\end{array}$ & $\begin{array}{c}\text { AUTOMATIC } \\
\text { DATA- } \\
\text { PROCESSIN } \\
\text { G MACHINES }\end{array}$ & $\begin{array}{c}\text { AUTOMATIC } \\
\text { DATA- } \\
\text { PROCESSIN } \\
\text { G MACHINES }\end{array}$ \\
\hline $\mathrm{CZ}$ & 8,56 & 17,29 & 19,74 & 18,65 & 23,68 \\
\hline & $\begin{array}{l}\text { TELECOMMUNICATIO } \\
\text { NS EQUIPMENT }\end{array}$ & $\begin{array}{l}\text { TELECOMMU } \\
\text { NICATIONS } \\
\text { EQUIPMENT }\end{array}$ & $\begin{array}{c}\text { TELECOMMUNIC } \\
\text { ATIONS } \\
\text { EQUIPMENT }\end{array}$ & $\begin{array}{l}\text { TELECOMMU } \\
\text { NICATIONS } \\
\text { EQUIPMENT }\end{array}$ & $\begin{array}{c}\text { TELECOMMU } \\
\text { NICATIONS } \\
\text { EQUIPMENT }\end{array}$ \\
\hline $\mathrm{HU}$ & 18,91 & 41,01 & 49,67 & 56,54 & 42,66 \\
\hline & $\begin{array}{l}\text { BABY CARRIAGES, } \\
\text { TOYS, GAMES AND } \\
\text { SPORTING GOODS }\end{array}$ & $\begin{array}{l}\text { TELECOMMU } \\
\text { NICATIONS } \\
\text { EQUIPMENT }\end{array}$ & $\begin{array}{l}\text { PARTS AND } \\
\text { ACCESSORIES } \\
\text { MACHINES }\end{array}$ & $\begin{array}{l}\text { TELECOMMU } \\
\text { NICATIONS } \\
\text { EQUIPMENT }\end{array}$ & $\begin{array}{l}\text { TELECOMMU } \\
\text { NICATIONS } \\
\text { EQUIPMENT }\end{array}$ \\
\hline PL & 9,76 & 8,60 & 11,61 & 12,20 & 11,75 \\
\hline & FOOTWEAR & $\begin{array}{l}\text { TELECOMMU } \\
\text { NICATIONS } \\
\text { EQUIPMENT }\end{array}$ & $\begin{array}{c}\text { TELECOMMUNIC } \\
\text { ATIONS } \\
\text { EQUIPMENT }\end{array}$ & $\begin{array}{l}\text { TELECOMMU } \\
\text { NICATIONS } \\
\text { EQUIPMENT }\end{array}$ & $\begin{array}{c}\text { TELECOMMU } \\
\text { NICATIONS } \\
\text { EQUIPMENT }\end{array}$ \\
\hline $\mathrm{RO}$ & 12,77 & 9,65 & 33,01 & 39,06 & 12,77 \\
\hline & $\begin{array}{l}\text { BABY CARRIAGES, } \\
\text { TOYS, GAMES AND } \\
\text { SPORTING GOODS }\end{array}$ & $\begin{array}{l}\text { TELECOMMU } \\
\text { NICATIONS } \\
\text { EQUIPMENT }\end{array}$ & $\begin{array}{c}\text { TELECOMMUNIC } \\
\text { ATIONS } \\
\text { EQUIPMENT } \\
\end{array}$ & $\begin{array}{l}\text { TELECOMMU } \\
\text { NICATIONS } \\
\text { EQUIPMENT }\end{array}$ & $\begin{array}{l}\text { TELECOMMU } \\
\text { NICATIONS } \\
\text { EQUIPMENT }\end{array}$ \\
\hline SK & 8,52 & 47,19 & 31,94 & 35,67 & 22,30 \\
\hline
\end{tabular}

Source: calculations from Eurostat

The pattern of trade between China and CEE- 6 has changed somewhat in the last decade. In certain cases concentration increased and in other areas decreased.

17 http://www.czech.cz/en/Comercio/Czech-beer-exports-to-China-doubled-last-year

$18 \mathrm{http} / / /$ www.praguepost.com/food-and-drink/49628-cefc-gains-79-percent-in-pivovary-lobkowicz 
These structural changes generally resulted in the increase of high-tech intensity of trade in certain CEE countries. The high tech export volume and share to China has been the highest in the case of Hungary and quite high for the Czech Republic but low in the case of the other countries. In general the CEE-China trade is much more hightech intensive than the CEE-EU trade (Éltetö-Szunomár 2015).

The high technology intensity of trade is mainly due to the above described large flows of automotive, electronic and telecommunications products. This is based on the activity of multinational companies in the global production networks (see ÉltetöToporowski 2013 and Ando-Kimura, 2013 as already mentioned). The bulk of foreign trade between CEE countries and China has been and still can be bound to certain products and certain (multinational) companies. Because the volume of trade is relative small (compared to for example the trade with EU or Germany) a one decision of a global company concerning relocation or change in internal deliveries among affiliates can significantly change the trade volumes of a given country vis-á-vis China. Relocating plants from Hungary, for example, decreased the Hungarian export capacity to Asia significantly in 2012-13 ${ }^{19}$.

Figure 7. Share of foreign value added in exports, $2011, \%$

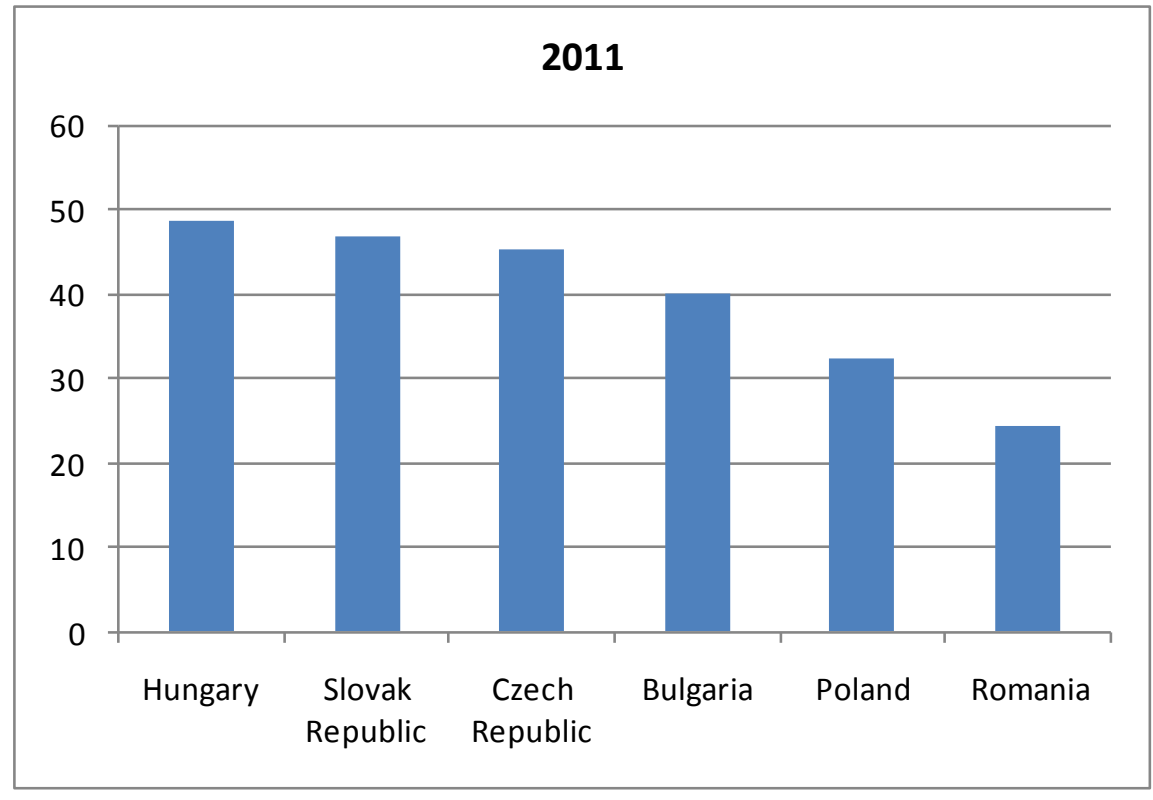

Source: TiVA database $(O E C D-W T O)^{20}$

The observed pattern of CEE-China trade reinforces that they are differently integrated into the GVCs. This has been already shown at worldwide trade level. Based on world input-output table data, Timmer et al. (2012) show that the use of imported intermediate inputs and the inclusion in global value chains have increased

19 In 2012 Nokia downgraded its affiliate in Hungary, switched assembly to Nokia's plants in South Korea and in Beijing. Therefore, in 2012 the previously huge export of cellular phones from Hungary decreased. In 2014 Microsoft (the owner of Nokia Komárom) announced the closure of the firm.

20 https://stats.oecd.org/index.aspx?queryid=66237 
radically between 1995 and 2008 in the case of the Central and Eastern European countries. Stehrer and Stöllinger (2012) have similar results when analysing forty countries. They use the foreign value added content of exports as a measure of vertical specialisation and GVC inclusion. Between 1995 and 2011 this foreign value added increased in almost all observed countries. Based on these data Hungary, the Czech Republic, Slovakia and even Bulgaria are especially strongly linked to GVCs (see Figure 7), but Poland and Romania to a lesser extent. These latter are large countries, Polish and Romanian export structure is more dispersed and, in general, the effect of foreign multinational companies on export seems to be lower than in other CE countries.

\section{Conclusion}

In our paper we analysed Chinese investment in the Central and Eastern European countries as well as mutual trade relations.

Regarding investment, our paper showed that Chinese investors have mostly searched for markets in CEE countries as the region's EU membership allows Chinese companies to treat the CEE region as a 'back door' to the affluent EU markets (tariff-jumping FDI). Chinese investors are attracted by the relatively low labor costs, skilled workforce, and market potential. It is characteristic that their investment pattern in terms of country location resembles that of the world total FDI in the region. Our paper also showed that the CEE region (including the selected group of countries) is not homogeneous and that there are differences in the economic relations and strategies between CEE countries and East Asia, too.

The global financial crisis had further accelerated the development of China-CEE economic relations as CEE countries started to search for new opportunities for their recovery from the recession. For example, Hungary's "Opening to the East" policy was initiated after (and partly as a result of) the crisis, but the crisis also made Poland, Romania and Bulgaria look eastward. China took these opportunities and has increased sectoral representation of Chinese firms in CEE countries in recent years. Another reason for this higher Chinese representation could be a diversification strategy, because recently Chinese global investment strategy places great emphasis on diversification in all respects. After the crisis, both mergers and acquisitions and joint venture investments started to become more and more popular among Chinese investors in the CEE region as their motivations have expanded toward strategic-asset and efficiency seeking. According to our research results, this process will continue in the future.

Overall, it can be stated that FDI and trade are closely connected. If Chinese firms buy companies in CEE countries that can enhance mutual trade. The internal trade of a multinational firm among its affiliates in CEE and China can also increase trade flows. Investment behaviour and motivation of Chinese firms in the CEE area can be 
explained best by the eclectic paradigm of Dunning with a special regard to the role of state.

CEE countries are not homogeneous either regarding the trade intensity or the dispersion of Chinese investment. The trade structure of three Visegrád countries differs from Poland, Romania and Bulgaria. Czech Republic, Slovakia and Hungary are included in the global production networks at another level. Their production and trade are more based on high tech products, mainly in the car and electronic industry. Regarding Poland, Bulgaria and Romania, they supply China with copper, wood and other low-tech products.

In our paper we have found that the bulk of trade flows between China and the CEE countries can well be explained and described by the theory and literature on global production networks.

\section{References}

Amador, J. - di Mauro, F (2015): The Age of Global Value Chains: Maps and Policy Issues. CEPR Press. A VoxEu.org e book: http://www.voxeu.org/content/age-global-value-chains-maps-andpolicy-issues

Amighimi, A. (2005) 'China in the international fragmentation of production: Evidence from the ICT industry', The European Journal of Comparative Economics, 2, 2.

Ando, M., Kimura, F. (2013): Production Linkage of Asia and Europe via Central and Eastern Europe. Journal of Economic Integration vol.28, no.2. June, p. 204-240.

Barrientos, S., G., Gereffi, A., \& Rossi (2010).Economic and Social Upgrading in Global Value Chains: Developing a Framework for Analysis, , Capturing the Gains Working Paper No. 2010/03,

Beltramello A., De Backer K. \& Moussiegt L. (2012) The Export Performance of Countries within Global Value Chains, Working Papers no. 2 (OECD, Directorate for Science, Technology and Industry).

Buckley PJ, Clegg JL, Cross AR, Liu X, Voss H and Zheng P (2007). The determinants of Chinese outward foreign direct investment. Journal of International Business Studies 38, 499-518.

Cattaneo, O. Gereffi, G., Miroudot, S., \& Taglioni, D. (2013). Joining, Upgrading and Being Competitive in Global Value Chains. A Strategic Framework. World Bank Policy Research Working Paper no. 6406, April.

Damijan J., Crt K. \& Rojec M. (2013): Global Supply Chains at Work in Central and Eastern European Countries: Impact of FDI on export restructuring and productivity growth, LICOS Discussion Paper Series no. 332, KU Leuven.

Dunning JH, Lundan SM (2008). Institutions and the OLI Paradigm of the Multinational Enterprise, Asia Pacific Journal of Management 25, pp. 573-593.

Éltető A -Szunomár Á (2015): Ties of Visegrád countries with East Asia - trade and investment. Budapest: Institute of World Economics, Centre for Economic and Regional Studies, Hungarian Academy of Sciences, 2015. 29 p. (IWE Working Papers; 214.)

Éltetö A - Toporowski, P. (2013): Effects of the international crisis - development of four Central European countries' trade with Asia. Paper presented at the $15^{\text {th }}$ ETSG conference, Birmingham, 12-14 September. http://www.etsg.org/ETSG2013/Papers/297.pdf

Éltető A - Völgyi K: The development of Hungarian Foreign Trade with Asia. Budapest: Institute of World Economics, Centre for Economic and Regional Studies, Hungarian Academy of Sciences, 2013. 41 p. (IWE Working Papers; 200.) 
N. Foster-McGregor and R. Stehrer (2013): "Value Added Content of Trade: A Comprehensive Approach" Economics Letters, 120, 354-357.

Gereffi, G., Humphrey, J.- Sturgeon, T. (2005). The governance of global value chains. Review of International Political Economy, 12(1), 78-104.

Gereffi, G. (2013): Global value chains in a post-Washington Consensus world, Review of International Political Economy, vol. 21 no. 1 (February, 2014), pp. 9-37

Gereffi, G. - Lee, J. (2014). Economic and Social Upgrading in Global Value Chains and Industrial Clusters: Why Governance Matters. Journal of Business Ethics, September 2014

Humphrey, J., \& Schmitz, H. (2002). How does insertion into global value chains affect upgrading in industrial clusters? Regional Studies, Vol. 36., No. 9.

IMF (2012): Changing Patterns of Global Trade. Departmental Paper no. 12/1 (Washington DC, International Monetary Fund).

Jacoby, W. (2014): Different cases, different faces: Chinese investment in Central and Eastern Europe. Asia Europe Journal vol.12, p. 199-214.

Kalotay, K.- Sulstarova,A. (2010): Modelling Russian outward FDI, Journal of International Management, Vol. 16, No. 2, 2010, p. 131-142.

Kalotay, K. - Éltetö, A. - Sass, M. - Weiner, Cs. (2014): Russian capital in the Visegrad countries. Institute of World Economics Working Paper no. 210.

Kimura F., Takahashi Y. \& Hayakawa K. (2005) Fragmentation and Parts and Components Trade: Comparison between East Asia and Europe. Manuscript.

Koopman, Z. R. Wang and S.J. Wei (2014): "Tracing Value-Added and Double Counting in Gross Exports" American Economic Review, 104(2): 459-94.

Lall S., Albaladejo M. \& Zhang J. (2004) Mapping fragmentation: Electronics and automobiles in East Asia and Latin America, Working Paper Series (QEH), February.

Liu Z. (2014): The Analysis of China's Investment in V4 In: Current Trends and Perspectives in Development of China-V4 Trade and Investment. University of Economics in Bratislava, Faculty of International Relations, 2014

Leitao NC, Faustino HC (2010). Portuguese Foreign Direct Investments Inflows: An Empirical Investigation. International Research Journal of Finance and Economics, Issue 38, pp 190-197.

Mathews, J. A.(2006: Dragon Multinationals: New players in 21st century globalization. Asia Pacific Journal of Management 23: p. 5-27

Matura T. (2013): China's Economic Expansion into Central Europe, In: Asian Studies (ed.: Tamas Matura), Hungarian Institute of International Affairs, pp. 138-151.

McCaleb A., Szunomár Á. (2014): Chinese foreign direct investment in Central and Eastern Europe: an institutional perspective. Unpublished manuscript

Milberg, W. \& D. Winkler (2011), -Economic and Social Upgrading in Global Value chains: Problems of Theory and Measurement, International Labour Review, 150(3-4), pp. 341-365.

Nölke, A. - Vliegenthart, A. (2009): Enlarging the Varieties of Capitalism: The Emergence of Dependent Market Economies in East Central Europe. World Politics, vol.61, no.4, p.670-702.

Pencea, S. - Oehler Sincai, I.M (2014): Romania, Strategic Partner in China-CEE Relations. Paper presented at the second China-CEE Forum, organized by the Institute of Russian, East European and Central Asian Studies (IREECAS), Chinese Academy of Social Sciences (CASS), 16-17 October 2014

Tuszynski, R. (2015): Polish Perspectives on CE-China 16+1 Cooperation: The Unexpected Ukrainian Factor. Europolity, vol.9, no.1 pp.189-190.

Rahman, Jesmin-Zhao, Tianli (2013): Export performance in Europe: The role of vertical supply links. IMF Working Paper, no. 62, March 
Resmini, L (2005). FDI, Industry Location and Regional Development in New Member States and Candidate Countries: A Policy Perspective, Workpackage No 4, 'The Impact of European Integration and Enlargement on Regional Structural Change and Cohesion, EURECO, $5^{\text {th }}$ Framework Programme, European Commission.

Srholec, M. (2005) High-tech exports from developing countries: A symptom of technology spurts or statistical illusion?, TIK Working Papers on Innovation Studies (Oslo, Centre for Technology, Innovation and Culture, University of Oslo).

Stehrer, R., Stöllinger, R. (2012): Positioning Austria in the Global Economy: Value Added Trade, International Production Sharing and Global Linkages. WIIW, FIW.

Song L. (2013): From rediscovery to new cooperation: The relationship between China and Central and Eastern Europe. EU-China Observer, Issue 5 2013, pp 8-14.

Szczudlik-Tatar, J. (2014): China's New Silk Road Diplomacy. PISM Policy paper no. 34, December

Szunomár Á, Völgyi K, Matura T (2014): Chinese investments and financial engagement in Hungary. Working Paper, No. 208, Institute of World Economics - MTA KRTK

Szunomár Á. (ed) (2014): Chinese investments and financial engagement in Visegrad countries: myth or reality? Budapest: Institute of World Economics, Centre for Economic and Regional Studies, Hungarian Academy of Sciences, $178 \mathrm{p}$.

Timmer M. P.- Los B.,- Stehrer R., - De Vries G. (2012): Fragmentation, incomes and jobs. An analysis of European competitiveness. WIOD Working paper, no. 9.

Timmer,M.P, - Erumban, A. - Los,B. - Stehrer, R - de Vries GJ (2014): Slicing Up Global Value Chains. Journal of Economic Perspectives, 28(2), 99-118.

Turcsányi R. Q. (2014): Chinese financial presence in Slovakia and Slovak 'China policy'. In: Szunomár Á. (ed) (2014): Chinese investments and financial engagement in Visegrad countries: myth or reality? Budapest: Institute of World Economics, Centre for Economic and Regional Studies, Hungarian Academy of Sciences, pp 89-107.

UNCTAD (2013): World Investment Report. Global Value Chains: Investment and Trade for Development (Geneva).

Vogiatzoglou K. (2012) Global production networks and export expansion: Cross-sectoral evidence from China, Working Paper (International Network for Economic Research), 2012/7.

Woon LJ (2003). Asian FDI in Central and Eastern Europe and its impact on the host countries. Asia Europe Journal 1, pp 349-369. 